\title{
Monoscleral fixation of IOL after extracapsular extraction of subluxated lenses in patients with Marfan syndrome
}

\author{
Fixação monoescleral da LIOapós ex tração extracapsulardecristalinos subluxados \\ em pacientes com síndrome deMarfan
}

\author{
Vinícius Coral Ghanem ${ }^{1}$ \\ Emir Amin Ghanem ${ }^{1}$ \\ Ramon Coral Ghanem² \\ Carlos Eduardo Leite Arieta ${ }^{3}$
}

\begin{tabular}{l} 
ABSTRACT \\
\hline Purpose: To describe a technique of monoscleral fixation of the intraocular \\
lens (IOL) after extracapsular extraction of subluxated lens in patients with \\
Marfan syndrome. Design: Noncomparative, interventional case series. \\
Methods: A retrospective study was conducted on 14 eyes of 7 consecutive \\
patients with subluxated lens associated with Marfan syndrome. Surgery \\
was indicated when: 1) a lens border was observed in the pupil area with \\
the pupil under normal lighting causing glare; or 2) the best corrected visual \\
acuity was less than 20/70; or 3 ) the patient complained of monocular \\
diplopia. Patients with a history of glaucoma, retinal detachment, trauma \\
or other systemic diseases were excluded. Results: The mean postoperative \\
follow-up was 15.43 \pm 9.33 months (range, 6 to 30 months). The best \\
spectacle-corrected visual acuity varied from $20 / 25$ to $20 / 60$, where $71.43 \%$ \\
reached 20/30 or better. No case showed a worsening of visual acuity, nor \\
were there any intraoperative or postoperative complications (intraocular \\
lens decentration, pupilar block, glaucoma or retinal detachment). The \\
most frequent postoperative complication was astigmatism, observed in \\
3 eyes (21.43\%) presenting values greater than 1.5 D. Conclusions: This \\
technique showed very good surgical and visual results and few compli- \\
cations, providing a surgical option for cases of ectopia lentis associated \\
with Marfan syndrome, especially in some countries or regions where \\
phacoemulsification is not available.
\end{tabular}

Keywords: Marfan syndrome; Ectopia lentis; Cataract extraction; Ophthalmologic surgical procedures; Intraocular lens implantation

\section{INTRODUCTION}

Ghanem - Joinville (SC).

Oftalmologista do Hospital de Olhos Sadalla Amin Ghanem - Joinville (SC).

${ }^{2}$ Médico Residente de Oftalmologia do quarto ano na Universidade de São Paulo (USP) - São Paulo (SP).

${ }^{3}$ Professor Assistente de Oftalmologia, Universidade Estadual de Campinas (UNICAMP) - Campinas (SP).

Endereço para Correspondência: Vinícius Coral Ghanem, Rua Fernando de Noronha, 225/901 - Joinville (SC) - CEP 89203-070

Email: vcghanem@hotmail.com

O autor não tem nenhum interesse financeiro nos produtos mencionados no estudo.

Nota Editorial: Pela análise deste trabalho e por sua anuência na divulgação desta nota, agradecemos aos Drs. Fábio Henrique Cacho Casanova e Walton Nosé.

Recebido para publicação em 20.08.2003

Versão revisada recebida em 20.04.2004

Aprovação em 23.04.2004
* Marfan AB. Un cas de déformation congénitale des quatre membres, plus pronocée aux extremités, characterisée par l'allongement des os avec un certain degré d'amincissement. Bull Soc Med Hop. 1896;13:220-6 apud Nelson LB, Maumenee IH. Ectopia lentis. Surv Ophthalmol. 1982;27(2):143-60. 
The most common ocular feature found is ectopia lentis due to marked zonular weakness. It is generally bilateral and superotemporal in direction ${ }^{(3)}$. Other ocular features include: astigmatism, axial myopia, flat cornea, glaucoma (due to incomplete development of angle structures), and retinal detachment (due to myopia and aphakia) ${ }^{(4-5)}$.

Various surgical techniques have been described for the treatment of ectopia lentis, among these are the following: sectorial iridectomy, intra- and extracapsular extraction of the lens, phacoemulsification, and limbal or pars plana lensecto$\mathrm{my}^{(4,6-12)}$.

However, there is still no consensus about which technique is the safest and most effective in these cases, especially in some countries or regions where automated equipment is scarce and phacoemulsification is not available.

The purpose of this study is to describe a surgical technique for extracapsular extraction of the subluxated lenses in these patients, associated with suture of one of the haptics of the intraocular lens (IOL) to the sulcus with the other being supported by the capsular remains, as well as its visual results and complications.

\section{METHODS}

A retrospective study was conducted on 14 eyes of 7 consecutive patients with Marfan syndrome who underwent surgery for the correction of spontaneous lens subluxation during the period from 1998 to 2000. Surgery was indicated when: 1) a lens border was observed in the pupil area with the pupil under normal lighting causing disabling glare; or 2) the best spectacle-corrected visual acuity (BSCVA) was less than 20/70; or 3 ) the patient complained of monocular diplopia. Patients with a history of glaucoma, retinal detachment, trauma or other systemic diseases were excluded.

All patients were operated on by the same surgeon (EAG), using the same surgical technique (described below). The interval between the surgeries of the first and the second eye of the same patient was about one month. Preoperative data included: age, sex, BSCVA, manifest refraction (when possible), applanation tonometry, biomicroscopy and dilated fundus examination with scleral indentation. Postoperative evaluation of IOL position and tilting was done using the slitlamp. No other evaluation method was used for this purpose.

\section{Surgical technique}

Pupil dilation was performed using 3 drops of $0.5 \%$ tropicamide and $10.0 \%$ phenylephrine at 15 minute intervals, one hour prior to surgery. Then peribulbar anesthesia was applied.

A limbal peritomy was performed and a scleral tunnel of $2.75 \mathrm{~mm}$ extension was made approximately $2 \mathrm{~mm}$ from the limbus, always $180^{\circ}$ from the place where there was still zonular integrity. This was evaluated during biomicroscopy by the slit-lamp with dilated pupils. In most cases the incision was made in the inferior sclera. Dispersive viscoelastic material was injected through the incision to maintain the anterior chamber and to prevent its collapse. An anterior continuous curvilinear capsulorhexis was performed between 4 and $6 \mathrm{~mm}$ in diameter. Hydrodissection was done with a flat cannula until the expulsion of the nucleus and cortex from the capsular bag. The nucleus and cortex material were removed from the anterior chamber using viscoelastic material and a Snellen loop, or aspirated with a Simcoe cannula.

A radial sclerotomy was then performed, in the center of the incision line, up to the iris root where a small iridotomy was done. A single piece polymethylmethacrylate (PMMA) lens was used with an optical zone of $6.5 \mathrm{~mm}$ and a total length of $13.5 \mathrm{~mm}$. Before inserting the IOL, one of the haptics was tied off with 10-0 prolene. The needle attached to the haptic was passed through the pupil, exiting at the iridotomy. The free haptic was inserted in the ciliary sulcus, and placed on the capsular support. The tied-off haptic was placed behind the iris, through the pupil, and attached to the sclera with a buried knot (Figure 1). The suture was done at the internal lip of the sclerotomy, near the iris root, thus the knot was not externally visible.

Throughout the entire procedure, viscoelastic material was used to maintain the anterior chamber depth. When necessary, an anterior vitrectomy was performed.

The scleral incision was sutured with $10-0$ mononylon. The final result is shown in figure 2 .

\section{Postoperative follow-up}

A combination of $0.3 \%$ tobramicin and $0.1 \%$ dexamethasone drops is applied every 4 hours through a period of 2 weeks, being tapered weekly over 45 days. When possible, a follow-

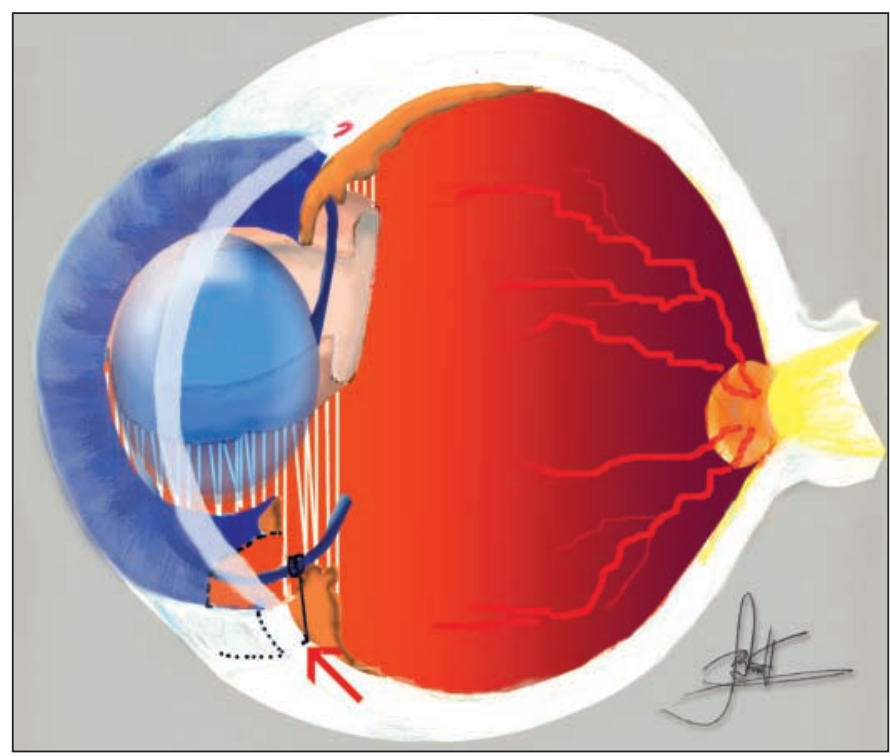

Figure 1 - The IOL is placed over the capsular support with one of its haptics inserted in the ciliary sulcus and the other fixed to the sclera with a buried knot (arrow) 


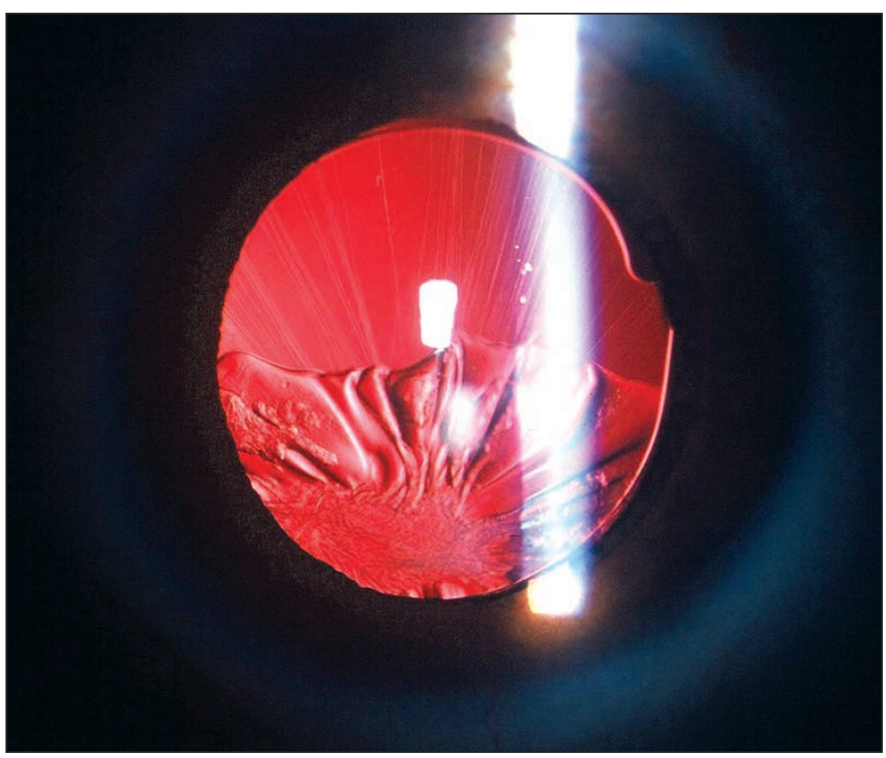

Figure 2 - The final result is shown on retroillumination. The IOL is placed over the capsular support

up examination was performed 1, 7 and 15 days and 1,2, 4 and 6 months postoperatively, and every 6 months thereafter.

\section{RESULTS}

Table 1 shows the pre- and postoperative data. Of the 7 patients, 5 were female $(71.43 \%)$ and 2 male $(28.57 \%)$. Mean age was $32.14 \pm 12$ years, ranging from 22 to 58 years. Preoperative BSCVA varied from counting fingers to 20/30. All patients presented lens subluxation: 6 eyes $(42.86 \%)$ with superior subluxation, 4 eyes (28.57\%) superotemporal, 2 eyes (14.29\%) inferotemporal and two eyes (14.29\%) nasally.
Main surgical indications were: decreased visual acuity in ten cases ( $71.43 \%$ - patients 1,2, 5 and 7, right eye of patients 3 and 6), glare in 3 cases (21.43\% - patient 4 and left eye of patient 6), and monocular diplopia in 1 case (7.14\% - left eye of patient 3). Varying degrees of lens opacification were observed in both eyes of patients 1 (intense) and 4 (mild). The IOL power used varied from 6.5 to 30 diopters (mean, 20.93D).

The mean postoperative follow-up was $15.43 \pm 9.33$ months varying from 6 to 30 months. Postoperative BSCVA varied from $20 / 25$ to $20 / 60$, in which $71.43 \%$ reached $20 / 30$ or better. No case showed a worsening in visual acuity, nor there were any intraoperative or postoperative complications (IOL tilt or decentration, pupilar block, glaucoma or retinal detachment). The most frequent complication was astigmatism in 3 eyes $(21.43 \%)$ presenting values greater than 1.5 . In five cases (35.71\% - patients 3, 6 and right eye of patient 1 ) the capsular bag remained in the visual axis, making it necessary to perform an Yttrium-Aluminium-Garnet (YAG) laser capsulotomy.

\section{DISCUSSION}

In patients with Marfan syndrome and with ectopia lentis, the main surgical indications are: 1) Low corrected vision; 2) Subluxated lens with its margin over visual axis causing glare; 3 ) monocular diplopia and 4) cataract. In some studies $^{(6,13)}$ the main indication for surgery was low corrected visual acuity. Glare and monocular diplopia were also important indications as they reduce visual quality. In our study, due to the fact that the patients were adults, these complaints were even more evident, as seen in 4 eyes (28.57\%) with BSCVA between 20/30 and 20/60 that underwent surgery.

Various techniques have already been discussed for the purpose of reducing complications and improving surgical

\begin{tabular}{|c|c|c|c|c|c|c|c|c|c|}
\hline $\begin{array}{l}\text { Patient } \\
\text { № }\end{array}$ & Sex & $\begin{array}{l}\text { Age } \\
\text { (yrs) }\end{array}$ & $\begin{array}{l}\text { Preop } \\
\text { refraction }\end{array}$ & $\begin{array}{l}\text { Preop } \\
\text { BSCVA }\end{array}$ & IOL power(D) & $\begin{array}{l}\text { Postop } \\
\text { refraction }\end{array}$ & $\begin{array}{l}\text { Postop } \\
\text { BSCVA }\end{array}$ & $\begin{array}{c}\text { Subluxation } \\
\text { pattern }\end{array}$ & Follow-up \\
\hline \multirow[t]{2}{*}{1} & $\mathrm{~F}$ & 58 & Impossible & Cf $1.5 \mathrm{~m}$ & 30.00 & $+0.50-3.00105^{\circ}$ & $20 / 30$ & Inferior/temporal & $30 \mathrm{mos}$ \\
\hline & & & Impossible & Cf $1.5 \mathrm{~m}$ & 30.00 & +2.50 & $20 / 25$ & Inferior/temporal & 30 mos \\
\hline \multirow[t]{2}{*}{2} & M & 28 & Impossible & $20 / 400$ & 20.00 & $-0.75-1.00 \quad 90^{\circ}$ & $20 / 30$ & Superior & $18 \mathrm{mos}$ \\
\hline & & & Impossible & Cf $2 m$ & 20.50 & $-1.25-0.5090^{\circ}$ & $20 / 30$ & Superior & $18 \mathrm{mos}$ \\
\hline \multirow[t]{2}{*}{3} & $\mathrm{~F}$ & 26 & $-1.00-1.2560^{\circ}$ & $20 / 80$ & 17.50 & $-2.25-1.00 \quad 45^{\circ}$ & $20 / 30$ & Superior/temporal & $24 \mathrm{mos}$ \\
\hline & & & $-2.00-4.50170^{\circ}$ & $20 / 60$ & 18.00 & $-1.25-1.0030^{\circ}$ & $20 / 60$ & Superior/temporal & $24 \mathrm{mos}$ \\
\hline \multirow[t]{2}{*}{4} & $\mathrm{~F}$ & 32 & $+5.00-2.0050^{\circ}$ & $20 / 30$ & 8.00 & $-1.5070^{\circ}$ & $20 / 30$ & Superior & $18 \mathrm{mos}$ \\
\hline & & & $-5.50-1.50105^{\circ}$ & $20 / 40$ & 6.50 & $-1.2570^{\circ}$ & $20 / 30$ & Superior & $18 \mathrm{mos}$ \\
\hline \multirow[t]{2}{*}{5} & M & 33 & Impossible & $20 / 200$ & 26.00 & $-1.50-1.25120^{\circ}$ & $20 / 25$ & Nasal & $6 \mathrm{mos}$ \\
\hline & & & Impossible & $20 / 400$ & 23.00 & $-1.25-1.50150^{\circ}$ & $20 / 40$ & Nasal & $6 \mathrm{mos}$ \\
\hline \multirow[t]{2}{*}{6} & $\mathrm{~F}$ & 26 & $-2.50-1.00 \quad 45^{\circ}$ & $20 / 80$ & 20.00 & $+1.50-1.0045^{\circ}$ & $20 / 40$ & Superior & $6 \mathrm{mos}$ \\
\hline & & & $-4.00-5.50180^{\circ}$ & $20 / 60$ & 18.00 & $+2.50-2.2550^{\circ}$ & $20 / 30$ & Superior & $6 \mathrm{mos}$ \\
\hline \multirow[t]{2}{*}{7} & $\mathrm{~F}$ & 22 & Impossible & Cf $40 \mathrm{~cm}$ & 26.50 & $-0.75-4.50155^{\circ}$ & $20 / 60$ & Superior/temporal & $6 \mathrm{mos}$ \\
\hline & & & Impossible & Cf $50 \mathrm{~cm}$ & 29.00 & $-0.50-0.50110^{\circ}$ & $20 / 30$ & Superior/temporal & $6 \mathrm{mos}$ \\
\hline
\end{tabular}


results ${ }^{(4,6-12)}$. The procedures most commonly used today are phacoemulsification and limbal or pars plana lensectomy, with or without IOL implantation ${ }^{(6-9,13-14)}$. Other studies ${ }^{(7,14)}$ reported good results and few complications for nontraumatic subluxations using limbal and pars plana lensectomy ${ }^{(7)}$ without IOL implant. To avoid aphakia, there are some options with similar results: after lensectomy and anterior vitrectomy, anterior chamber lens can be used ${ }^{(6)}$. However, other authors $^{(9,15-16)}$ used scleral fixation of the IOL (with better results when performed in the ciliary sulcus), and more currently using the posterior chamber IOLs associated with scleral fixation of the endocapsular tension $\operatorname{ring}^{(8,11)}$. In our technique, the support of the IOL optic or only one of its haptics in capsular remains and the suture of the other haptic in the sclera, keeps the IOL stable, preventing tilting and decentration, as observed in other studies ${ }^{(15,17)}$. One could expect that a progressive zonular disease might cause the non-fixed haptic of the IOL to drop years later. We do not believe that this will happen for two main reasons: 1) after the first few months of surgery, the empty capsular bag contracts towards the intact zonular fibers and becomes fibrotic, giving excellent support for the non-fixed haptic, and 2) even in Marfan patients who did not undergo cataract surgery, the complete lens luxation is rare ${ }^{(4)}$.

In this study, apart from the vast majority of patients $(85.7 \%)$ showing a significant improvement of the BSCVA after surgery, almost $30 \%$ of the eyes had 20/40 or worse. As all patients were adults, without previous ophthalmologic evaluation, it is therefore believed that a great part of visual loss would be due to ambliopia.

Even without significant per- or postoperative surgical complications, a mean follow-up of 15.43 months could be insufficient for a long-term safety evaluation, as retinal detachment may can occur up to several years after surgery ${ }^{(10)}$.

Although several studies ${ }^{(6-7,9,11,13-14)}$ have shown good results with techniques other than extracapsular cataract extraction associated with the scleral fixation of IOL in the ciliary sulcus, this can be considered a surgical option for cases of ectopia lentis associated with Marfan syndrome, and probably it can be used in subluxations of other etiologies (however other studies are required to evaluate this idea) where there are zonular and capsular supports for the IOL, and apart from very good surgical results and few complications, it is easy to perform.

\section{CONCLUSION}

This technique showed very good surgical and visual results and few complications, providing a surgical option for cases of ectopia lentis associated with Marfan syndrome, especially in some countries or regions where phacoemulsification is not available.

\section{ACKNOWLEDGEMENT}

We thank Drs. Lígia Beatriz Bonotto and Claiton Rolin for spending their precious time to draw figure 1 of this article.

\section{RESUMO}

Objetivo: Descrever a técnica de fixação monoescleral da lente intra-ocular (LIO) após extração extra-capsular de cristalinos subluxados em pacientes com síndrome de Marfan. Métodos: Estudo retrospectivo conduzido em 14 olhos de 7 pacientes atendidos consecutivamente com subluxação do cristalino associada à síndrome de Marfan. A cirurgia foi indicada quando: 1) a margem do cristalino era observada na área pupilar, em condições normais de iluminação, causando ofuscamento visual; ou 2) a melhor acuidade visual corrigida era menor que 20/70; ou 3) o paciente queixava-se de diplopia monocular. Foram excluídos pacientes com história de glaucoma, descolamento de retina, trauma ou outras doenças sistêmicas. Resul-

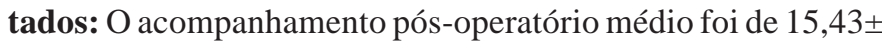
9,33 meses (variação, 6 a 30 meses). A melhor acuidade visual corrigida com óculos variou de 20/25 a 20/60, dos quais $71,43 \%$ alcançaram 20/30, ou melhor. Nenhum caso mostrou piora da acuidade visual, além de não terem sido observadas complicações per ou pós-operatórias (descentração da lente intra-ocular, bloqueio pupilar, glaucoma ou descolamento de retina). A complicação pós-operatória mais freqüente foi o astigmatismo, observando-se valores maiores que 1,5 dioptrias em 3 casos $(21,43 \%)$. Conclusões: Esta técnica mostrou bons resultados cirúrgicos e visuais, além de poucas complicações, sendo opção cirúrgica para os casos de subluxação do cristalino associada com a síndrome de Marfan, especialmente em alguns países ou regiões onde a facoemulsificação não está disponível.

Descritores: Síndrome de Marfan, Ectopia lentis, Extração da catarata, Procedimentos cirúrgicos oftalmológicos, Implantação da lente intra-ocular

\section{REFERENCES}

1. Nelson LB, Maumenee IH. Ectopia lentis. Surv Ophthalmol 1982;27:143-60

2. Prockop DJ, Kuivaniemi H, Tromp G. Heritable disorders of connective tissue. In: Isselbacher KJ, Braunwald E, Wilson JD, Martin JB, Fauci AS, Kasper DL. Harrison's Textbook of Medicine, $13^{\circ}$ ed. New York, NY: McGray-Hill; 1994. p.2224-5.

3. Nelson LB, Maumenee IH. Ectopia lentis. Surv Ophthalmol. 1982;27(3):143-60.

4. Maumenne IH. The eye in the Marfan syndrome. Trans Am Ophthalmol Soc. 1981;79:684-733

5. Sallum JMF, Chen J, Perez ABA. Anomalias oculares e características genéticas na síndrome de Marfan. Arq Bras Oftalmol. 2002;65(6):623-8.

6. Koenig SB, Mieler WF. Management of ectopia lentis in a family with Marfan Syndrome. Arch Ophthalmol. 1996;114(9):1058-61.

7. Hakin KN, Jacobs M, Rosen P, Taylor D, Cooling RJ. Management of the subluxed crystalline lens. Ophthalmology. 1992;99(4):542-5.

8. Lam DS, Young AL, Leung AT, Rao SK, Fan DS, Ng JS. Scleral fixation 
of a capsular tension ring for severe ectopia lentis. J Cataract Refract Surg. 2000;26(4):609-12.

9. Omulecki W, Nawrocki J, Palenga-Pydyn D, Sempinska-Szewczyk J. Pars plana vitrectomy, lensectomy, or extraction in transscleral intraocular lens fixation for the management of dislocated lenses in a family with Marfan's syndrome. Ophthalmic Surg Lasers. 1998;29(5):375-9.

10. Varga B. The results of my operations improving visual acuity of ectopia lentis. Ophthalmologica. 1971;162(2):98-110.

11. cionni RJ, Osher RH. Management of profound zonular dialysis or weakness with a new endocapsular ring designed for scleral fixation. J Cataract Refract Surg. 1998;24(10):1299-306. Commented in: J Cataract Refract Surg. 2001; 27(11):1710-1

12. Rossi JV, Soares PHL, Torigoe AMS, Fujii GY, Silva VB. Vitrectomia para luxação do cristalino ou fragmentos para o segmento posterior. Rev Bras Oftalmol. 2003;62(4):297-304

13. Halpert M, BenEzra D. Surgery of the hereditary subluxated lens in children. Ophthalmology. 1996;103(4):681-6.

14. Plager DA, Parks MM, Helveston EM, Ellis FD. Surgical treatment of subluxated lenses in children. Ophthalmology. 1992;99(7):1018-21; discussion 1022-3.

15. Zetterstrom C, Lundvall A, Weeber H Jr, Jeeves M. Sulcus fixation without capsular support in children. J Cataract Refract Surg. 1999;25(6):776-81.

16. Trimarchi F, Stringa M, Vellani G, Iato MS. Scleral fixation of an intraocular lens in the absence of capsular support. J Cataract Refract Surg. 1997;23(5):795-7.

17. Gunenc U, Erkin EF, Maden A, Tekin N, Ergin MH. Monoscleral fixated lens implantation in eyes with partial loss of capsular or zonular support. J Cataract Refract Surg. 1997;23(5):710-3.

\section{REUNIÃO DO CENTRO DE ESTUdOS OFTALMOLÓGICOS "CYRO DE REZENDE"}

\section{2 a 04 de Dezembro de 2004 \\ Centro de Convenções de Ribeirão Preto - SP}

Departamento de Oftalmologia, Otorrinolaringologia e Cirurgia de Cabeça e Pescoço da Faculdade de Medicina da USP de Ribeirão Preto

Tema: "Superfície Ocular"

INFORMAÇÕES: Eventus Planejamento e Organização

Fone: (1 1) 3361-3056 - Fax: (1 1) 3361-3089

E-mail: oftalmo@eventus.com.br

Home-page: www.eventus.com.br/oftalmo 